\title{
A new species of Hedgpethia (Arthropoda, Pycnogonida, Colossendeidae) from southwestern Japan
}

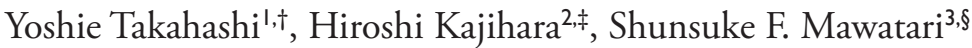 \\ I Sapporo Daiichi High School, Sapporo 062-0021, Japan 2 Faculty of Science, Hokkaido University, Sapporo \\ 060-0810, Japan 3 The Hokkaido University Museum, Sapporo 060-0810, Japan \\ † urn:lsid:zoobank.org:author:56C5776B-455D-4EAE-8A20-DADE66438FD3 \\ † urn:lsid:zoobank.org:author:D43FC916-850B-4F35-A78C-C2116447C606 \\ § urn:lsid:zoobank.org:author:323734E7-A545-4533-AE47-70C2672FD85D \\ Corresponding author: Hiroshi Kajihara (kazi@mail.sci.hokudai.ac.jp)
}

Academic editor: J. Dunlop | Received 31 December 2011 | Accepted 8 March 2012 | Published 16 March 2012

urn:lsid:zoobank.org:pub:CD0AD49A-7024-49EE-8D5D-4B667635ECB2

Citation: Takahashi Y, Kajihara H, Mawatari SF (2012) A new species of Hedgpethia (Arthropoda, Pycnogonida, Colossendeidae) from southwestern Japan. ZooKeys 175: 69-74. doi: 10.3897/zookeys.175.2612

\begin{abstract}
We describe Hedgpethia spinosa sp. n. based on a single male specimen obtained from 197-207 m depth, south of Yaku Island, Kagoshima Prefecture, Japan. Among 15 previously known congeners, the new species resembles H. bicornis (Losina-Losinsky \& Turpaeva, 1958), H. chitinosa (Hilton, 1943), and probably H. brevitarsis (Losina-Losinsky \& Turpaeva, 1958), in having a mid-dorsal tubercle on the posterior rim on each trunk segment. The new species, however, is distinguishable from those by a pair of horns on the anterior margin of the cephalic segment, spines on the first coxae, and denticulate spines on the strigilis. The new species represents the fifth member of the genus so far known from Japanese waters, in addition to H. brevitarsis (Losina-Losinsky \& Turpaeva, 1958), H. chitinosa (Hilton, 1943), H. dofleini (Loman, 1911), and H. elongata Takahashi, Dick \& Mawatari, 2007.
\end{abstract}

\section{Keywords}

Pantopoda, Nansei Islands, TRV Toyoshio-maru, new species, taxonomy

\section{Introduction}

Pycnogonids have been taxonomically relatively well studied in Japan, beginning with Böhm's (1879) report of two new species from Enoshima, Sagami Bay; about 160 species have now been recorded from Japanese waters (Miyazaki and Stock 1995, Na-

Copyright Yoshie Takahashi et al. This is an open access article distributed under the terms of the Creative Commons Attribution License 3.0 (CC-BY), which permits unrestricted use, distribution, and reproduction in any medium, provided the original author and source are credited. 
kamura 1995, Child 1996, Nakamura et al. 1996, Takahashi et al. 2007). While most studies have focused on the Pacific coast of central Japan, there have been fewer reports of pycnogonids from waters adjacent to the Nansei Islands, from where 23 species in 17 genera belonging to nine families have so far been recorded (Ohshima 1935, Nakamura and Child 1988, Child 1996, Takahashi et al. 2007).

The colossendeid genus Hedgpethia Turpaeva, 1973 contains 15 species (Arango 2009, Bamber 2010). All of these are fairly small in body size compared to most species of Colossendeis, the type genus of Colossendeidae. Species of Hedgpethia have been collected from a wide range of depths, from $20 \mathrm{~m}$ [H. chitinosa (Hilton, 1943) (Utinomi 1971: 338)] to $4294 \mathrm{~m}$ [H. articulata (Loman, 1908) (Turpaeva 1994: 135)]; most species have been collected infrequently, at only a few sites. From Japanese waters, four species of Hedgpethia have been reported so far, viz. H. brevitarsis (Losina-Losinsky \& Turpaeva, 1958) (Nakamura and Child 1983, 1991), H. chitinosa (Hilton, 1943) (Hedgpeth 1949, Utinomi 1955, 1962, 1971, Nakamura and Child 1983, 1991, Nakamura 1987), H. dofleini (Loman, 1911) (Loman 1911, Hedgpeth 1949, Utinomi 1951, 1955, 1971, Nakamura and Child 1991), and H. elongata Takahashi, Dick and Mawatari, 2007 (Takahashi et al. 2007).

During a research cruise of the Training and Research Vessel Toyoshio-maru, Hiroshima University, in May 2005, a specimen of Hedgpethia was procured. We describe it as a new species in this paper.

\section{Material and methods}

Collection, preparation, and measurements of the specimens primarily follow the methods of Takahashi et al. (2007). The voucher specimen has been deposited in the Hokkaido University Museum, Sapporo, Japan (ZIHU).

\section{Results}

\section{Hedgpethia spinosa sp. $\mathrm{n}$.}

urn:lsid:zoobank.org:act:C228D530-5701-46F7-894F-EC12941C99C7

http://species-id.net/wiki/Hedgpethia_spinosa

Fig. 1

Material examined. Holotype: male, ZIHU 3335, 30 08.90'N, $130^{\circ} 38.04^{\prime} \mathrm{E}$, south of Yaku Island, Kagoshima, 26 May 2005, 197-207 m depth, collected by plankton net in a beam trawl [inner net sensu Akiyama et al. (2008)], S. Ohtsuka leg.

Measurements of holotype (millimeters). Trunk length, 1.28; body width, 0.62; length of proboscis, 1.43 ; length of abdomen, 0.08 ; length of palp, 2.26; first article of palp (P1), 0.06; P2, 0.03; P3, 0.83; P4, 0.10; P5, 0.50; P6, 0.14; P7, 0.12; P8, 0.15; P9, 0.16; P10, 0.17; third leg, coxa 1, 0.21; coxa 2, 0.18; coxa 3, 0.16; femur, 1.33; 

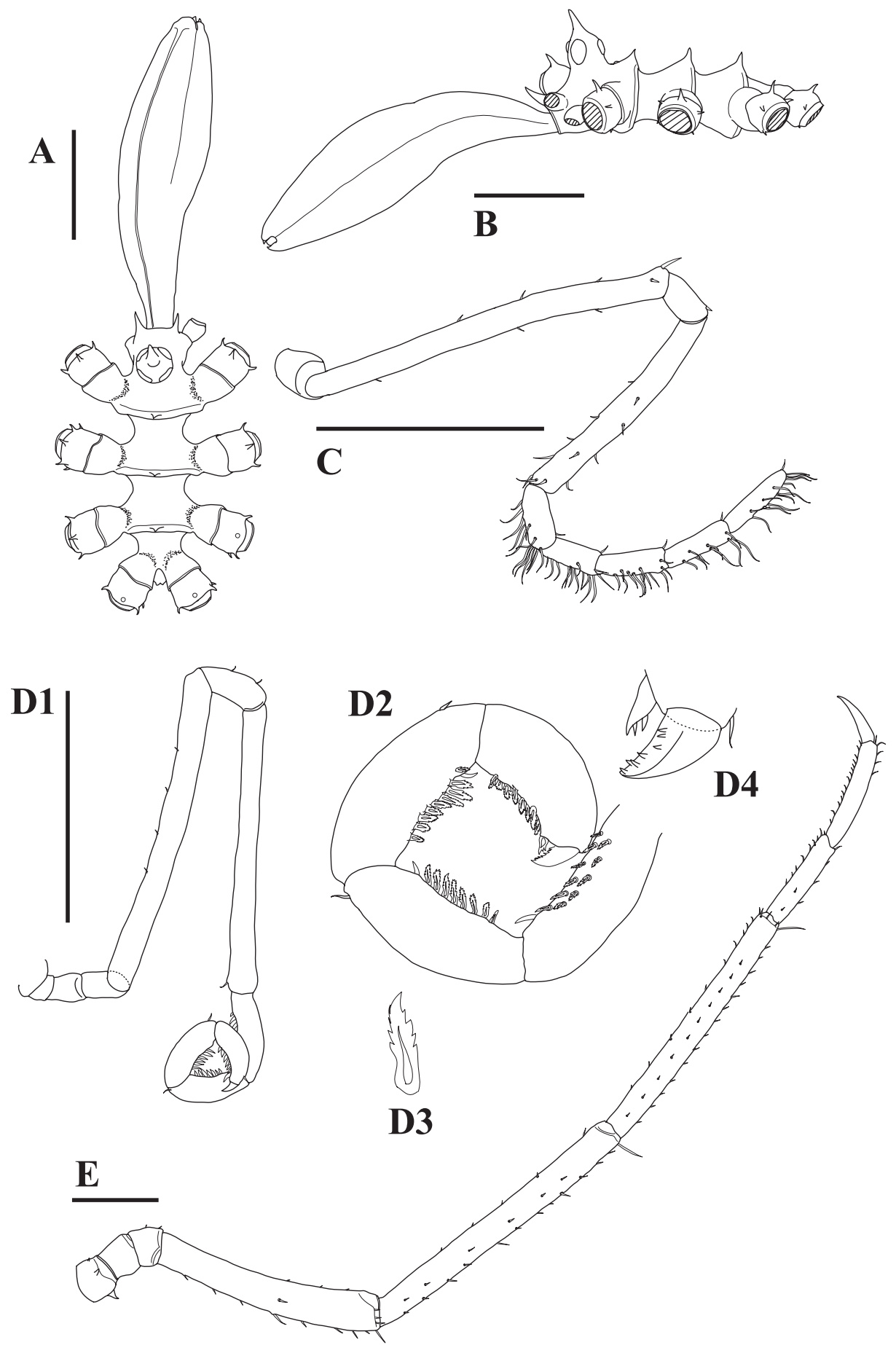

Figure I. Hedgpethia spinosa sp. n. Holotype, male (ZIHU 3335). A trunk, dorsal view B trunk, lateral view $\mathbf{C}$ palp D I oviger D2 enlargement of distal segments of oviger D3 enlargement of denticulate spine constituting strigilis D4 enlargement of terminal claw of oviger $\mathbf{E}$ left third leg. Scale bars: $0.5 \mathrm{~mm}$. 
tibia 1, 1.73; tibia 2, 1.52; tarsus, 0.56; propodus, 0.65; claw, 0.33; oviger, first article (O1), 0.04; O2, 0.11; O3, 0.11; O4, 1.20; O5, 0.21; O6, 1.18; O7,0.21; O8, 0.19; O9, 0.19; O10, 0.14.

Description. Size small for genus, leg span only $6.5 \mathrm{~mm}$. Trunk (Fig. 1A, 1B) moderately short for genus, completely segmented, posterior rims of segments 1-3 inflated, each with pointed dorsal median tubercle. Lateral processes almost as long as their basal width, separated from one another by slightly more than their basal width, glabrous. Cephalic segment with pair of horn-like spines at anterior margin. Ocular tubercle dome shaped, 1.5 times as high as its basal width, with pointed apex projecting slightly forward. Eyes slightly pigmented, anterior pair larger than posterior pair. Proboscis (Fig. 1A, 1B) 1.2 times as long as trunk, swollen, spindle shaped, constricted at middle of total length, slightly curved downward, tapering distally; lips rounded, each with short ciliary sheet. Abdomen very small, located on ventral side.

Palps (Fig. 1C) longer than proboscis, slender; 10-segmented, with two short basal segments; first segment about twice as wide as other segments; second segment shortest; third segment longest, straight, with sparse, short setae, and with a few longer setae dorsodistally; fourth segment same length as sixth; fifth segment 0.6 times as long as third, with sparse setae over entire surface of distal half; seventh, eighth, and ninth segments subequal to sixth segment in length and slightly shorter than terminal segment; distal five segments fairly setose ventrally, setae as long as segment width, each segment with single short dorsodistal seta.

Oviger (Fig. 1D1) slender, long, 10-segmented; fourth and sixth segments longest, with very tiny setae ectally; fifth segment almost as long as second and third combined; strigilis (Fig. 1D2) armed with single short seta ectodistally, with rows of slender endal spines having denticles (Fig. 1D3); seventh segment equal to fifth in length; terminal segment less than two-thirds length and width of seventh segment; terminal claw short, about one-fifth as long as terminal segment, having small spines endally (Fig. 1D4).

Legs (Fig. 1E) slender, with many tiny setae over entire surface; first coxa with one small spine dorsally, one or two spines anteriorly and posteriorly, respectively; first and third coxae subequal and shorter than second coxa; femur almost equal to second tibia in length, curved ventrally, thickened in distal half, with several longer setae on distal end; tibia straight, with single long seta on distal end; first tibia 1.3 times as long as femur; tarsus slightly longer than propodus, both segments with dense, short setae ventrally and sparse, short setae dorsally; main claw about two-thirds as long as propodus.

Etymology. The specific name, a Latin adjective, refers to the spines on first coxae, anterior trunk margin, and terminal claw of oviger.

Remarks. Three species of Hedgpethia have pointed dorsomedian tubercles: H. bicornis (Losina-Losinsky \& Turpaeva, 1958), H. chitinosa (Hilton, 1943), and probably H. brevitarsis (Losina-Losinsky \& Turpaeva, 1958), the tubercles of which are slightly rounded. However, none of these has a pair of horns on the anterior margin of the cephalic segment, spines on the first coxae, or denticulate spines on the strigilis. The anterior spines of the cephalic segment have the appearance of vestiges of chelifores. This is one of the smallest species in the genus. 


\section{Acknowledgements}

We thank Professor Susumu Ohtsuka, Hiroshima University, for his kindness in giving the first author the opportunity to take part in his research cruise, and for his generosity in offering us the valuable specimen, and the crew of TRV Toyoshio-maru, Hiroshima University, for their kind assistance on board.

\section{References}

Akiyama T, Shimomura M, Nakamura K (2008) Collection of deep-sea small arthropods: gears for collection and processing of samples on deck. Taxa, Proceedings of the Japanese Society of Systematic Zoology 24: 27-32. [In Japanese with English summary]

Arango CP (2009) New species and new records of sea spiders (Arthropoda: Pycnogonida) from deep waters in Western Australia. Zootaxa 1977: 1-20.

Bamber RN (2010) Hedgpethia Turpaeva, 1973. In: Bamber RN, El Nagar A (Eds) Pycnobase: World Pycnogonida Database. Accessed through World Register of Marine Species at http://www.marinespecies.org/aphia.php?p=taxdetails\&id=134587 on 15 August 2011.

Böhm R (1879) Über zwei neue von Herrn Dr. Hilgendorf in Japan gesammelte Pycnogoniden. Sitzungsberichte der Gesellschaft naturforschender Freunde zu Berlin 1879(4): 53-60.

Child CA (1996) Pycnogonida of the western Pacific islands, XII. A recent diving survey of Okinawa, Ryukyu Islands. Proceedings of the Biological Society of Washington 109(3): 540-559.

Hedgpeth JW (1949) Report on the Pycnogonida collected by the Albatross in Japanese waters in 1900 and 1906. Proceedings of the United States National Museum 98: 233-321.

Hilton WA (1943) Pycnogonids from the Pacific. Family Colossendeidae. Journal of Entomology and Zoology of Pomona Collage 35(1): 2-4.

Loman JCC (1908) Die Pantopoden der Siboga-Expedition. Siboga Expeditie Monographie 40: $1-88$.

Loman JCC (1911) Beiträge zur Naturgeschichte Ostasiens. Herausgegeben von Dr. F. Doflein. Abhandlungen der mathematisch-physikalischen Klasse der Königlich Bayerischen Akademie der Wissenschaften 4 (Supplement 2): 1-18.

Losina-Losinsky LK, Turpaeva EP (1958) The genus Colossendeis (Pantopoda) in the northern part of the Pacific Ocean. Byulleten Moskovskovo Obshchestva Ispytatelei Prirody 63(1): 23-33. [In Russian with English summary]

Miyazaki K, Stock JH (1995) Rhynchothorax mediterraneus, the first record of Rhynchothoracidae (Pycnogonida) from Japan. Publications of the Seto Marine Biological Laboratory 36: 325-327.

Nakamura K (1987) The Sea Spiders of Sagami Bay, Collected by His Majesty the Emperor of Japan. Biological Laboratory, Imperial Household, Tokyo, x +43 pp. (English text), 40 pls, 35 pp. (Japanese text), 2 maps.

Nakamura K (1995) Pycnogonida. In: Nishimura S (Ed.) Guide to Seashore Animals of Japan with Color Pictures and Keys, Vol. 2. Hoikusha, Osaka, 34-41. [In Japanese]

Nakamura K, Child CA (1983) Shallow-water Pycnogonida from the Izu Peninsura, Japan. Smithsonian Contributions to Zoology 386: 1-71. doi: 10.5479/si.00810282.386 
Nakamura K, Child CA (1988) Pycnogonida of the western Pacific islands, 4: on some species from the Ryukyu Islands. Proceedings of the Biological Society of Washington 101: 662-670.

Nakamura K, Child CA (1991) Pycnogonida from waters adjacent to Japan. Smithsonian Contributions to Zoology 512: 1-74. doi: 10.5479/si.00810282.512

Nakamura K, Miyazaki K, Child CA (1996) Shallow-water Pycnogonida from Ogasawara (Bonin) Islands with a description of Achelia curticauda n. sp. Species Diversity 1: 117-121.

Ohshima H (1935) [On a sea spider inhabiting the Okinawa region]. Zoological Magazine, Tokyo 47(557): 137-139. [In Japanese]

Takahashi Y, Dick MH, Mawatari SF (2007) Sea spiders (Arthropoda: Pycnogonida) from waters adjacent to the Nansei Islands of Japan. Journal of Natural History 41(1-4): 61-79. doi: 10.1080/00222930601121783

Turpaeva EP (1973) Mnogokolenchatye (Pantopoda) iz severo-vostochnoi chasti tikhogo okeana. Trudy Instituta Okeanologii 91: 178-191. [In Russian]

Turpaeva EP (1994) Sea spiders (Pycnogonida) from the North Pacific Basin. Trudy Instituta Okeanologii im. P. P. Shirshova 131: 126-138. [In Russian with English summary]

Utinomi H (1951) On some pycnogonids from the sea around Kii Peninsula. Publications of the Seto Marine Biological Laboratory 1(4): 159-168.

Utinomi H (1955) Report on the Pycnogonida collected by the Soyo-Maru Expedition made on the continental shelf bordering Japan during the years 1926-30. Publications of the Seto Marine Biological Laboratory 5(1): 1-42.

Utinomi H (1962) Pycnogonida of Sagami Bay (Supplement). Publications of the Seto Marine Biological Laboratory 10(1): 91-104.

Utinomi H (1971) Records of Pycnogonida from shallow waters of Japan. Publications of the Seto Marine Biological Laboratory 18(5): 317-347. 